\begin{tabular}{|l|l|l|l|l|l|}
\hline J. Tek. Ling & Vol. 12 & No. 3 & Hal. 259 - 267 & Jakarta, September 2011 & ISSN 1441-318X \\
\hline
\end{tabular}

\title{
POTENSI BAKTERI DENITRIFIKASI DALAM BIODEGRADASI CARBARYL PADA KONDISI ANAEROBIK
}

\author{
Dwi Agustiyani \\ Peneliti di Bidang Mikrobiologi, Puslit Biologi-LIPI \\ titinagustin@yahoo.com
}

\begin{abstract}
Abstrak
Potensi bakteri denitrifikasi dalam mendegradasi senyawa Carbaryl dalam kondisi anaerobik dipelajari. Penelitian diawali dengan aklimatisasi kultur mikroba yang berasal dari tanah pertanian tercemar pestisida di daerah Lembang dan Dieng, dalam media denitrifikasi yang mengandung Carbaryl. Dari hasil aklimatisasi diperoleh 3 kultur mikroba denitrifikasi (CL, CD dan D3) yang mengindikasikan mampu tumbuh pada media yang mengandung 1000 ppm Carbaryl. Hasil isolasi dari ketiga kultur tersebut diperoleh 10 isolat bakteri murni. Enam isolat bakteri (CL1, CL2, CD1, CD2, D3.1, D3.2) diuji aktivitas denitrifikasi dan kemampuan degradasi Carbaryl pada kondisi anaerobik. Hasil pengujian menunjukkan bahwa keenam isolat bakteri mampu tumbuh dan melakukan aktivitas denitrifikasi serta memperlihatkan indikasi mampu mendegradasi Carbaryl, dengan terbentuknya senyawa 1-Naphtol. Reaksi denitrifikasi dan degradasi Carbaryl berlangsung secara simultan. Ada dua pola perubahan Carbaryl oleh bakteri denitrifikasi yang diuji, yaitu bakteri denitrifikasi yang hanya mampu merombak Carbaryl menjadi 1-Naphthol dan bakteri denitrifikasi yang dapat merombak Carbaryl menjadi 1-Naphthol dan senyawa tertentu lainnya (belum terdeteksi).
\end{abstract}

kata kunci : aktivitas denitrifikasi, aklimatisasi, Carbaryl, 1-Naphthol

\begin{abstract}
Potency of denitrifying bacteria on Carbaryl degradation under anaerobic condition was studied. Firstly, we acclimated and isolated denitrifying bacteria from the pesticide polluted-agriculture soil at Lembang and Dieng. Three microbe culture of denitrifying (C.L, C.D and D3) was obtained and all of the cultures indicated having growth capability on media containing 1000 ppm of Carbaryl. Ten isolate of denitrifying bacteria was obtained from those three microbe cultures. Furthermore, the denitrifying activity and capability of Carbaryl degradation of six isolate of denitrifying bacteria (CL1, CL2, CD1, $C D 2, D 3.1, D 3.2)$ were tested under anaerobic condition. The result shows that the denitrifying reaction and Carbaryl degradation were carried out simultaneously. From the experiment found that there were two kind pathway of Carbaryl degradation, 1) degradation of Carbaryl to 1-Naphtol and 2) Carbaryl to 1-Naphtol, 1-Naphtol to certain compound (was not detected yet).
\end{abstract}

key words : denitrification activity, acclimation, Carbaryl, 1-Naphthol 


\section{PENDAHULUAN}

Carbaryl (1-naphthyl $\mathrm{N}$-methylcarbamate) secara luas digunakan sebagai pestisida(1). Carbaryl memiliki toksisitas yang cukup tinggi, serta area aktivitas yang luas, dan banyak digunakan dalam industri pertanian(2). Karbamat sangat toksik dan menghambat acetylcholinesterase ${ }^{(3)}$, yaitu enzim yang mengatur fungsi sistem syaraf. Meskipun pestisida karbamat digunakan secara luas namun pestisida jenis ini pada umumnya tidak bersifat persisten di lingkungan untuk jangka waktu yang lama. Oleh karena penyebarannya yang luas dan digunakan secara berulang-ulang maka pestisida ini menjadi salah satu penyebab terjadinya pencemaran di tanah maupun di perairan ${ }^{(4)}$. Pencemaran pada perairan akibat praktek pertanian selain disebabkan oleh pestisida juga disebabkan oleh nitrat, dan kedua senyawa tersebut merupakan senyawa pencemar yang umum dan merupakan problem di area pertanian di diseluruh dunia. Di daerah yang pencemaran pestisidanya tinggi maka biasanya konsentrasi nitratnya juga tinggi(5). Oleh karena itu maka biodenitrifikasi merupakan teknik yang dapat diharapkan untuk merombak nitrat dan pestisida secara bersamaan dari lingkungan tanah maupun perairan. Perombakan nitrat dan pestisida secara biologis menggunakan teknik biodenitrifikasi dengan memanfaatkan substrat jerami gandum sebagai sumber karbon tambahan telah dipelajari dan hasilnya cukup efisien ${ }^{(6)}$.

Terjadinya kontaminasi senyawa pestisida dapat terjadi dari perpindahan pestisida dari zona perakaran kedalam air bawah tanah dan melalui aliran hujan masuk kedalam air permukaan. Pencemran pestisida juga dapat terjadi akibat penanganan yang tidak tepat terhadap limbah pestisida sehingga terjadi kebocoran dari tempat penyimpanan. Limbah pestisida juga dapat terbentuk dari sisa larutan pestisida atau larutan pestisida yang tidak terpakai, karena pestisida bersifat aqueous maka mudah mencemari lingkungan.

Salah satu cara yang cukup efisien dan aman untuk mengurangi pencemaran pestisida adalah menggunakan mikroba yang mampu mendegradasi pestisida menjadi senyawa lain yang tidak toksik. Dilaporkan bahwa degradasi yang dilakukan oleh mikroba berperan penting dalam reduksi pestisida $^{(1)}$, degradasi pestisida oleh mikroba biasanya berjalan sangat cepat. Beberapa jenis bakteri yang mempunyai kemampuan mendegradasi pestisida karbamat dapat diisolasi dari tanah ${ }^{(4,7)}$. Walaupun telah banyak laporan tentang degradasi carbaryl oleh mikroba tanah ${ }^{(3,7,8,9)}$, namun demikian alur reaksi degradasi yang sering dipelajari baru terbatas pada Pseudomonas dan Rhodococcus ${ }^{(7)}$. Tahap pertama proses degradasi yang dilakukan oleh bakteri adalah hidrolisis carbaryl menjadi produk 1-Naphthol oleh aktivitas enzim hydrolase carbaryl, enzim ini dapat ditemukan pada berbagai macam mikroorganisme, salah satunya bakteri denitrifikasi. Bergantung pada jenis mikroba, 1-Naphtol mengalami metabolisme melalui salisilat membentuk gentisate atau catechol. Baik produk 1-Naphthol, salisilat, dan gentisate, merupakan intermediet dari degradasi Carbaryl(2). Hasil penelitian lain melaporkan bahwa Carbaryl juga dapat dihidrolisis 1-Naphtol, methylamine dan $\mathrm{CO}_{2}{ }^{(10)}$.

Sampai saat ini biodegradasi Carbaryl pada kondisi anaerobik oleh bakteri denitrifikasi masih belum banyak dipelajari. Bakteri denitrifikasi adalah bakteri heterotrofik yang memerlukan karbon sebagai sumber energi. Apabila senyawa pestisida dapat digunakan sebagai sumber karbon oleh bakteri denitrifikasi maka potensi bakteri denitrifikasi sebagai agen bioremediasi pestisida dapat dikembangkan. Oleh karena itu maka dilakukanlah penelitian yang bertujuan mempelajari potensi bakteri denitrifikasi dalam mendegradasi Carbaryl dan Nitrat secara bersamaan pada kondisi anaerobik. 


\section{BAHAN DAN METODA}

\subsection{Sumber kultur dan isolat bakteri denitrifikasi}

Sumber kultur dan isolat bakteri denitrifikasi adalah tanah pertanian dari daerah Dieng dan Lembang, yang telah diperlakukan dengan pestisida secara intensif.

\subsection{Aklimatisasi bakteri denitrifikasi pendegradasi Carbaryl}

Untuk memperoleh bakteri denitrifikasi yang mampu mendegradasi Carbaryl dilakukan aklimatisasi tiga sampel tanah pada media cair Nutrient Broth (NB), ditambah dengan 500 ppm $\mathrm{KNO}_{3}$ dan 1000 ppm Carbaryl. Tiga sampel tanah yang digunakan adalah tanah pertanian intensif dari daerah Dieng (D), Lembang (L) dan tanah bekas pengoplosan pestisida, Dieng (D3). Tanah sebanyak 10 gram dimasukkan kedalam botol Scot $(500 \mathrm{ml})$ yang berisi 400 $\mathrm{ml}$ media cair. Kultur tersebut kemudian di inkubasi diatas shaker atau stirer. Selama aklimatisasi diamati perubahan konsentrasi Nitrat dan Amonium.

\subsection{Isolasi bakteri denitrifikasi}

Dari masing-masing kultur diinokulasi bakteri denitrifikasinya pada tabung reaksi yang berisi media Giltay yang dilengkapi dengan tabung durham. Pertumbuhan bakteri denitrifikasi dalam tabung diindikasikan dengan perubahan media menjadi biru dan terbentuknya gas pada tabung durham setelah inkubasi selama 14 hari. Dari tabung yang positip kemudian diisolasi bakteri denitrifikasinya pada petridish yang berisi media $\mathrm{NA}+\mathrm{KNO}_{3}$ dan Carbaryl. Kultur dalam petridish di inkubasi dalam Anaerocult. Koloni yang tumbuh pada petridish kemudian dimurnikan sehingga diperoleh isolat murni.

\subsection{Uji degradasi Carbaryl pada kondisi denitrifikasi \\ Enam isolat bakteri denitrifikasi (CL1, CL2, CD1, CD2, D3.1, D3.2) masing-masing}

ditumbuhkan dalam botol kecil (Vol $30 \mathrm{ml}$ ), yang berisi media denitrifikasi ( $\mathrm{NB}$ dan $\mathrm{KNO}_{3}$ ), diinkubasi selama 2 hari. Sebanyak $1 \mathrm{ml}$ kultur bakteri denitrifikasi dari masing-masing botol diambil dan dimasukkan ke dalam botol Schoot $(500 \mathrm{ml})$ yang telah berisi media cair denitrifikasi $\left(\mathrm{NB}+\mathrm{KNO}_{3}\right)$ dan 500 ppm Carbaryl. Satu botol Scot tidak diinokulasi dengan isolat bakteri denitrifikasi, sebagai kontrol. Kultur dalam botol Scot kemudian diberi perlakuan gas Argon (flushing) selama kurang lebih 25 menit untuk membuat kondisi menjadi anaerobik. Keenam botol Scot tersebut di inkubasi diatas shaker. Pada interval waktu 0, 5 dan 24 jam dilakukan pengambilan sampel sebanyak $9 \mathrm{ml}$ dari masing-masing botol untuk analisis Nitrat, Nitrit, Ammonium, 1-Naphtol dan pengukuran pertumbuhan bakteri dengan cara mengukur Optical Density (OD) pada panjang gelombang $436 \mathrm{~nm}$. Sampel yang akan digunakan untuk analisis nitrat, nitrit, amonium, dan 1-Naphtol terlebih dahulu disentrifugasi terlebih dahulu selama 10 menit dengan kecepatan 12.000 rpm.

\subsection{Penentuan pola pertumbuhan dan degradasi Carbaryl dari isolat terpilih Penentuan pola pertumbuhan dan} pola degradasi Carbaryl dilakukan pada isolat bakteri CL1 dan CD1. Kedua isolat ditumbuhkan dalam masing-masing botol Scot berukuran $(500 \mathrm{ml})$ yang berisi media denitrifikasi (NB + $2 \mathrm{gr} / \mathrm{L} \mathrm{KNO}_{3}$ ). Pada awal percobaan ( 0 jam) diambil sampel dari dalam botol sebanyak $9 \mathrm{ml}$ untuk dianalisis nitrat, nitrit, ammonium, dan 1-Naphtol. Kultur dalam botol kemudian diberi perlakuan gas Argon (flushing) kurang lebih $\mathbf{3 0}$ menit untuk membuat kondisi anaerobik. Kultur dalam botol kemudian diinkubasi diatas stirer, setiap interval waktu 3 jam sampel diambil, sampai jam ke 24 untuk dianalisis konsentrasi nitrat, nitrit, ammonium, dan 1-Naphtol dengan menggunakan Spektrofotometri.

\subsection{Analisis Nitrat $\left(\mathrm{NO}_{3}-\right)$}

Sebanyak 3,6 $\mathrm{ml}$ aquades $\mathrm{pH} 7$ dicampur dengan 0,4 ml sampel (pengenceran $10 \mathrm{x}$ ), 
dimasukkan ke dalam tabung reaksi besar. Kedalam tabung ditambahkan 0,8 ml larutan $\mathrm{NaCl} 30 \%$, dan $4 \mathrm{ml}$ larutan asam sulfat $\left(\mathrm{H}_{2} \mathrm{SO}_{4}\right) 75 \%$. Setiap penambahan larutan dilakukan pengocokan menggunakan vortex agar tercampur sempurna. Campuran tersebut di dinginkan terlebih dahulu untuk kemudian ditambahkan dengan 0,2 ml larutan campuran brusin dan asam sulfat. Tabung kemudian dipanaskan di dalam waterbath pada suhu $95^{\circ} \mathrm{C}$ selama 20 menit. Setelah larutan dingin, kemudian diukur konsentrasi $\mathrm{NO}_{3}$ dengan Spektrofotometer pada panjang gelombang ( $\lambda$ ) $410 \mathrm{~nm}$.

\subsection{Analisis Nitrit $\left(\mathrm{NO}_{2}-\right)$}

Sebanyak 4,5 $\mathrm{ml}$ aquades $\mathrm{pH} 7$ ditambahkan $0,5 \mathrm{ml}$ sampel ke dalam tabung reaksi (pengenceran $10 \mathrm{x}$ ). Ditambahkan $0,1 \mathrm{ml}$ larutan sulfanilamide kedalam tabung reaksi, kemudian dikocok dan dibiarkan selama kurang lebih 2-8 menit. Setelah itu ditambahkan lagi 0,1 ml larutan Ethylendiamine, dikocok dan didiamkan sampai 10 menit. Larutan kemudian di ukur dengan Spektrofotometri pada panjang gelombang $(\lambda) 543 \mathrm{~nm}$.

\subsection{Analisis Ammonium $\left(\mathrm{NH}_{4}\right)$}

Sebanyak 4,5 $\mathrm{ml}$ aquades $\mathrm{pH}$ 7 ditambahkan dengan $0,5 \mathrm{ml}$ sampel (pengenceran $10 \mathrm{x}$ ). Ditambahkan 0,05 ml Nessler A dan 0,05 ml Nessler B, dan dikocok sampai tercampur dengan sempurna. Diamkan sekitar 10 menit, kemudian diukur dengan Spektrofotometer pada panjang gelombang ( $\lambda$ ) $500 \mathrm{~nm}$.

\subsection{Analisis 1-Naphthol}

Sebanyak $1 \mathrm{ml}$ sampel dimasukkan ke dalam tabung reaksi kecil atau tabung eppendrof. Selanjutnya ditambahkan 0,1 reagen (campuran dodecyl dan fast blue B), kemudian divortex agar tercampur sempurna. Pengukuran dengan Spektrofotometri dilakukan pada panjang gelombang $(\lambda) 600 \mathrm{~nm}$. Larutan yang digunakan sebagai blanko adalah larutan media $\mathrm{NB}+\mathrm{KNO}_{3}$

\section{HASIL DAN PEMBAHASAN}

\subsection{Aklimatisasi bakteri denitrifikasi}

Untuk memperoleh bakteri denitrifikasi yang mampu mendegradasi Carbaryl, dilakukan aklimatisasi tiga sampel tanah dalam media denitrifikasi $\left(\mathrm{NB}+\mathrm{KNO}_{3}\right)$ yang mengandung 1000 ppm Carbaryl. Selama proses aklimatisasi, perubahan konsentrasi Nitrat dan Amonium diamati, dan hasilnya ditampilkan pada Tabel 1.

Terjadinya penurunan konsentrasi nitrat dan peningkatan konsentrasi amonium pada masing-masing kultur menunjukkan bahwa pada masing-masing kultur terjadi proses denitrifikasi (Tabel 1). Data ini menunjukkan bahwa ketiga kultur bakteri ini mampu melakukan proses denitrifikasi pada media yang mengandung 1000 ppm carbaryl, yang berarti kultur bakteri cukup resiten dengan carbaryl sehingga diharapkan bakteri di dalam kultur tersebut mampu mendegradasi senyawa carbaryl.

Tabel 1. Perubahan konsentrasi amonium dan nitrat selama aklimatisasi

\begin{tabular}{|c|c|c|c|c|}
\hline \multirow{2}{*}{ Sampel } & \multicolumn{2}{|c|}{ Awal aklimatisasi } & \multicolumn{2}{c|}{ Akhir aklimatisasi (2 minggu) } \\
\cline { 2 - 5 } & $\mathrm{NH}_{4}-\mathrm{N}(\mathrm{ppm})$ & $\mathrm{NO}_{3}-\mathrm{N}(\mathrm{ppm})$ & $\mathrm{NH} 4-\mathrm{N}(\mathrm{ppm})$ & $\mathrm{NO}_{3}-\mathrm{N}(\mathrm{ppm})$ \\
\hline $\mathrm{C} . \mathrm{D}$ & 1,38 & 9,61 & 112,80 & 0,42 \\
\hline $\mathrm{C} . \mathrm{L}$ & 1,21 & 9,36 & 114,11 & 0,43 \\
\hline $\mathrm{D} 3$ & 4,90 & 11,68 & 72,21 & 0,19 \\
\hline
\end{tabular}

Keterangan :

$\mathrm{D}=$ tanah pertanian Dieng, $\mathrm{L}=$ Tanah pertanian Lembang, $\mathrm{C}=$ Carbaryl

D3 = tanah bekas pengoplosan pestisida, Dieng 


\subsection{Isolasi bakteri denitrifikasi}

Dari masing-masing kultur diinokulasi bakteri denitrifikasinya pada tabung reaksi yang berisi media Giltay yang dilengkapi dengan tabung durham. Dari tabung yang positip kemudian diisolasi bakteri denitrifikasinya pada petridish yang berisi media $\mathrm{NA}+\mathrm{KNO}_{3}$ dan Carbaryl. Kultur dalam petridish di inkubasi dalam Anaerocult. Koloni yang tumbuh pada petridish kemudian dimurnikan sehingga diperoleh isolat murni. Hasil isolasi dari tiga kultur yang telah di aklimatisasi diperoleh 10 isolat murni (Tabel 2).

\subsection{Aktivitas denitrifikasi dan degradasi Carbaryl}

Berdasarkan hasil pengukuran Amonium, Nitrat, Nitrit, dan 1-Naphtol dari 6 isolat bakteri yang diuji, terindikasi adanya dua pola degradasi Carbaryl. Pada isolat bakteri CL1, CL2, D3.1, D3.2, terlihat konsentrasi Nitrat $\left(\mathrm{N}-\mathrm{NO}_{3}-\right)$ mengalami penurunan dari 0,5 , hingga 24 jam reaksi (Gambar 3). Penurunan konsentrasi nitrat diikuti oleh penurunan konsentrasi nitrit $\left(\mathrm{N}-\mathrm{NO}_{2}-\right)$ (Gambar 4) dan peningkatan amonium $\left(\mathrm{N}-\mathrm{NH}_{4}\right)$ (Gambar 2). Data ini

Tabel 2. Isolat bakteri denitrifikasi

\begin{tabular}{|l|l|}
\hline \multicolumn{1}{|c|}{ Sumber isolat } & \multicolumn{1}{|c|}{ Isolat murni } \\
\hline Tanah pertanian, Lembang (L) & CL1, CL2 \\
\hline Tanah pertanian, Dieng (D) & CD1, CD2, CD3, CD4, CD5, CD6 \\
\hline $\begin{array}{l}\text { Tanah dari area pengoplosan pestisida, } \\
\text { Dieng (D3) }\end{array}$ & D3(1), D3(2) \\
\hline
\end{tabular}

\subsection{Pertumbuhan bakteri denitrifikasi}

Enam isolat dari 10 isolat bakteri denitrifikasi yang berhasil di isolasi, diuji kemampuan tumbuhnya pada media yang mengandung 500 ppm Carbaryl. Enam isolat bakteri yang diuji adalah : isolat CL1, CL2, CD1, CD2, D3.1, D3.2. Keenam isolat bakteri yang diuji mampu tumbuh pada media denitrifikasi, isolat CL1 dan CL2 memperlihatkan pertumbuhan yang relatif lebih tinggi dibandingkan dengan isolat bakteri lainnya (Gambar 1).

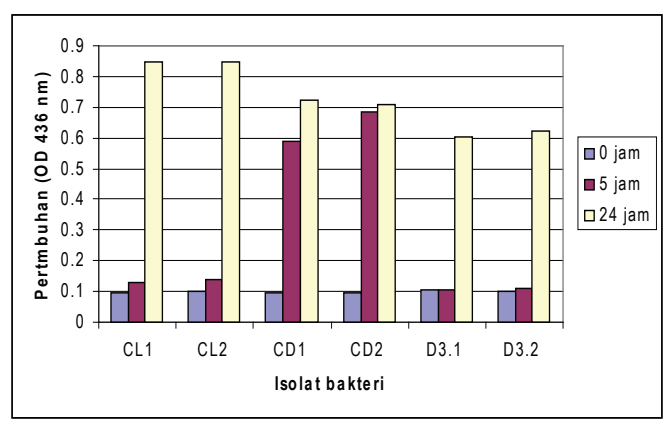

Gambar 1. Pertumbuhan (OD $436 \mathrm{~nm}$ ) selama 24 jam dari 6 isolat bakteri mengindikasikan terjadinya proses reduksi nitrat yang dilanjutkan dengan reduksi nitrit. Peningkatan amonium mengindikasikan adanya reaksi reduksi nitrit menjadi amonium, atau kemungkinan merupakan hasil samping dari degradasi Carbaryl. Seperti diperlihatkan pada Gambar 5, konsentrasi 1-Naphtol dari 4 isolat bakteri (CL1, CL2, D3.1, D3.2) mengalami peningkatan dari 0,5 , hingga 24 jam reaksi. Data ini memperlihatkan kemungkinan terjadinya reaksi degradasi Carbaryl menjadi 1-Naphtol. Dari data diatas dapat disimpulkan bahwa keempat isolat bakteri tersebut mampu mendegradasi Carbaryl menjadi 1-Naphtol.

Pola yang berbeda ditunjukkan oleh isolat CD1 dan CD2 yang memperlihatkan adanya penurunan konsentrasi nitrat (Gambar 3), diikuti dengan peningkatan konsentrasi nitrit (Gambar 4). Konsentrasi amonium pada awalnya meningkat, namun setelah 24 jam reaksi mengalami penurunan kembali (Gambar 2). Sedangkan konsentrasi 1-Naphtol meningkat, akan tetapi tidak setinggi seperti pada 4 isolat bakteri (CL1, CL2, D3.1, D3.2) (Gambar 5). Data ini 
mengindikasikan adanya kemungkinan terjadinya reaksi degradasi Carbaryl menjadi 1-Naphtol, dan kemudian 1-Naphtol mengalami degradasi lebih lanjut menjadi senyawa tertentu yang belum diketahui. Terjadinya peningkatan konsentrasi nitrit kemungkinan merupakan hasil samping dari degradasi 1-Naphtol atau indikasi terhambatnya proses denitrifikasi yaitu terhambatnya reaksi reduksi nitrit sehingga senyawa nitrit terakumulasi.

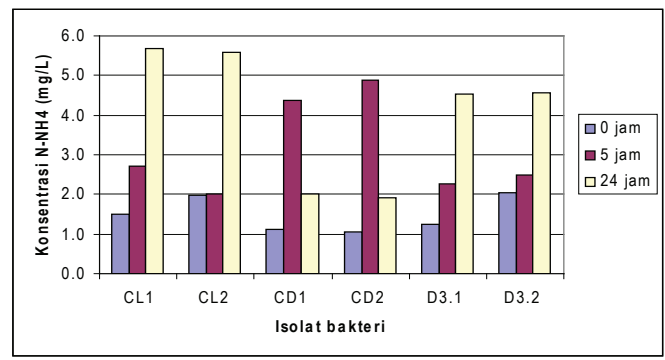

Gambar 2. Perubahan konsentrasi amonium selama 24 jam dari 6 isolat bakteri

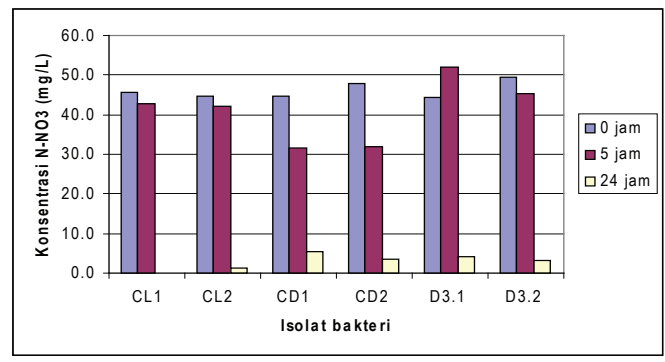

Gambar 3. Perubahan konsentrasi nitrat $\left(\mathrm{NO}_{3}^{-}\right)$selama 24 jam dari 6 isolat bakteri

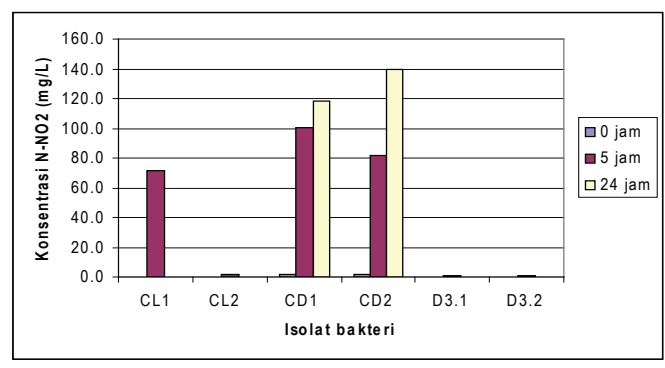

Gambar 4. Perubahan konsentrasi Nitrit $\left(\mathrm{NO}_{2}{ }^{-}\right)$selama 24 jam dari 6 isolat bakteri

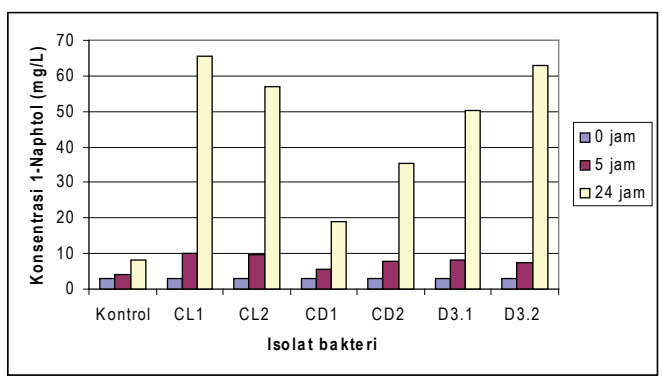

Gambar 5. Perubahan konsentrasi 1-Naphtol selama 24 jam dari 6 isolat bakteri

\subsection{Pola pertumbuhan, aktivitas denitrifikasi dan degradasi Carbaryl dari isolat terpilih}

Penentuan pola pertumbuhan dan degradasi Carbaryl pada kondisi denitrifikasi dilakukan pada dua isolat bakteri denitrifikasi CD1 dan CL1. Kurva pertumbuhan dua isolat bakteri (CL1 dan CD1) menunjukkan pola yang berbeda. Pada isolat bakteri CL1, fase lag berlangsung cukup lama sampai jam ke-9, dan memasuki fase eksponensial dengan cepat sampai jam ke-21 hingga mencapai absorbansi 2,8 . Selanjutnya memasuki fase stasioner dan kematian sampai jam ke-24 (Gambar 6A). Sedangkan fase lag isolat bakteri CD1 berlangsung cepat hingga jam ke-3, selanjutnya masuk fase eksponensial dengan pertumbuhan yang lambat, yaitu hanya mencapai absorbansi 1,2 hingga jam ke-72 (Gambar 6B).

Pola perubahan konsentrasi Nitrogen dari isolat CL1 ditampilkan pada Gambar 7. Konsentrasi nitrat $\left(\mathrm{N}-\mathrm{NO}_{3}-\right.$ ) mulai mengalami penurunan pada jam ke-9 dan hampir habis pada jam ke-18. Penurunan konsentrasi nitrat diikuti oleh kenaikan konsentrasi nitrit $\left(\mathrm{NO}_{2}-\right)$ pada jam ke-12 dan kemudian konsentrasi nitrit mengalami penurunan kembali hingga tidak terdeteksi lagi. Sedangkan konsentrasi amonium $\left(\mathrm{NH}_{4}\right)$ sedikit mengalami peningkatan. Data ini mengindikasikan terjadinya reaksi denitrifikasi yang cukup baik dari isolat CL1. 

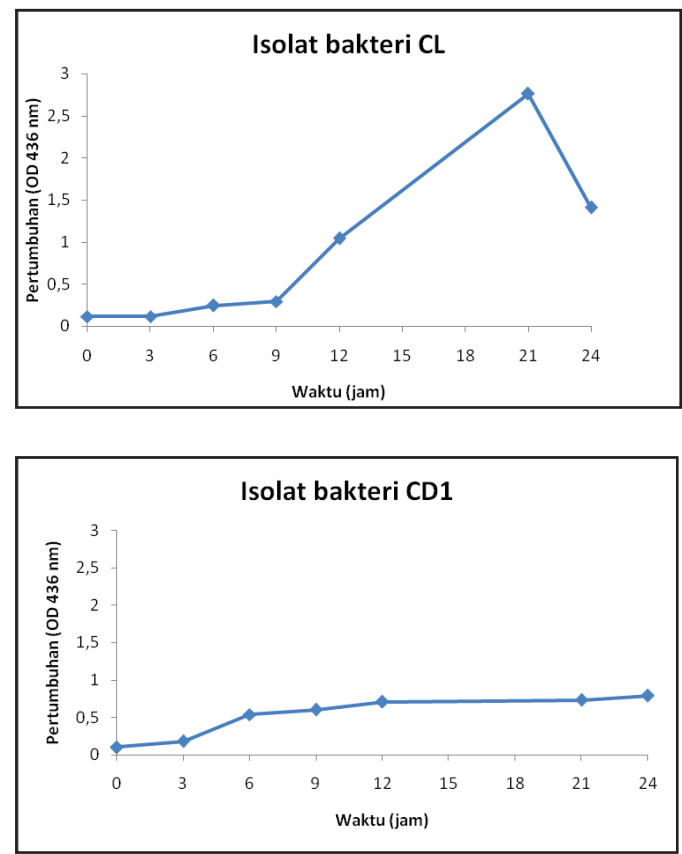

Gambar 6. Kurva pertumbuhan isolat bakteri CL1 (Gambar 6A), CD1 (Gambar $6 B)$.

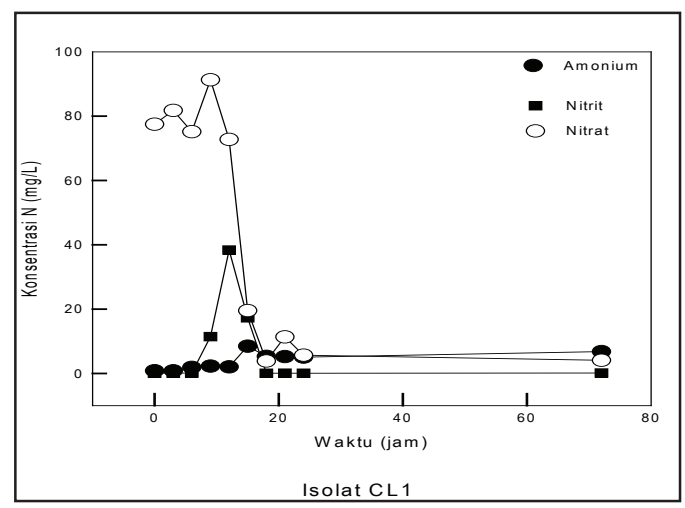

Gambar 7. Pola perubahan konsentrasi Nitrogen dari isolat bakteri CL1

Pola perubahan konsentrasi 1-Naphtol oleh isolat CL1 terlihat pada Gambar 8. Konsentrasi 1-Naphtol mengalami sedikit peningkatan sampai jam ke 15 , dan meningkat cepat setelah jam ke 15 sampai jam ke 24. Konsentrasi 1-Naphtol yang terbentuk cukup tinggi, selama 24 jam reaksi mencapai $>800$ ppm. Terbentuknya 1-Naphtol mengindikasikan adanya reaksi

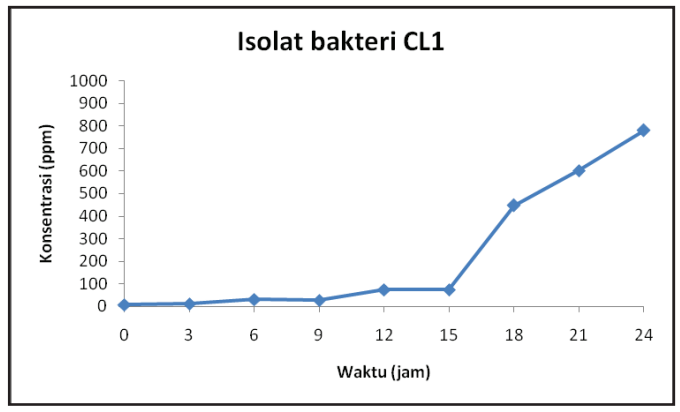

Gambar 8. Pola perubahan konsentrasi 1-Naphtol dari isolat bakteri CL1

degradasi Carbaryl. Telah dilaporkan bahwa tahap pertama proses degradasi yang dilakukan oleh bakteri adalah hidrolisis carbaryl menjadi produk 1-Naphthol oleh aktivitas enzim hydrolase carbaryl(2).

Pola perubahan konsentrasi Nitrogen dari isolat CD1 tampak berbeda dengan isolat $\mathrm{CL} 1$. Konsentrasi nitrat $\left(\mathrm{N}-\mathrm{NO}_{3}{ }^{-}\right)$ mengalami sedikit penurunan dan kenaikan kembali secara bertahap sampai jam ke21. Selanjutnya setelah fase tersebut, konsentrasi mengalami penurunan kembali hingga tidak terdeteksi lagi pada jam ke-72 (Gambar 9). Penurunan konsentrasi nitrat diikuti oleh kenaikan konsentrasi nitrit (N$\mathrm{NO}_{2}-$ ), pada jam ke-15 konsentrasi nitrit turun hingga mendekati nilai 0 . Akan tetapi, pada jam ke-21 konsentrasi nitrit mengalami kenaikan kembali hingga mencapai 150 ppm. Kenaikan konsentrasi nitrit yang sangat tinggi kemungkinan sebagian hasil dari perombakan Carbaryl dan sebagian dari reduksi nitrat yang merupakan bagian dari proses denitrifikasi. Jika dibandingkan dengan isolat bakteri CL1, tampak bahwa reaksi denitrifikasi dari isolat CD1 lebih lambat.

Pada Gambar 10 ditunjukkan bahwa konsentrasi 1-Naphtol pada awalnya menurun dan meningkat pada jam ke-9 hingga mencapai konsentrasi 70 ppm pada jam ke-15. Setelah itu konsentrasi 1-Naphtol mengalami penurunan lagi pada jam ke-18, dan kembali meningkat pada jam ke-21 


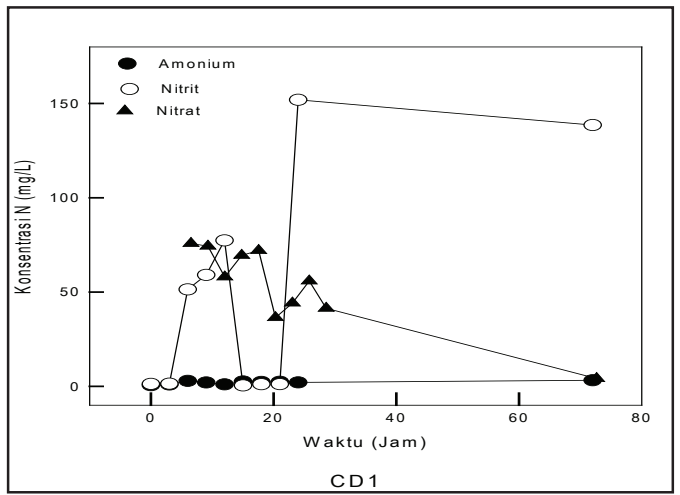

Gambar 9. Pola perubahan konsentrasi nitrogen dari isolat bakteri CD1

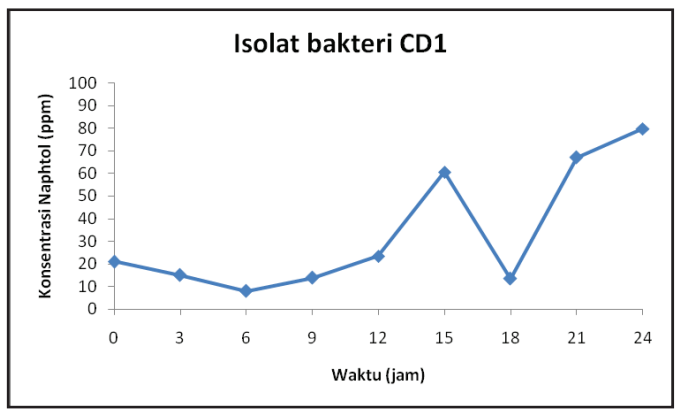

Gambar 10. Pola perubahan konsentrasi 1-Naphtol dari isolat bakteri CD1

hingga jam ke-24. Dari pola perubahan 1-Naphtol diduga bahwa Carbaryl mulai diubah menjadi 1-Naphtol pada sekitar jam ke 9, dan 1-Naphtol tersebut kemudian diubah menjadi senyawa tertentu yang belum terdeteksi (Gambar 9). Dilaporkan bahwa 1-Naphtol merupakan tahap awal dari proses perombakan Carbaryl, selanjutnya 1-Naphtol mengalami metabolisme melalui salisilat membentuk gentisate atau catechol. Baik produk 1-Naphthol, salisilat, dan gentisate, merupakan intermediet dari degradasi Carbaryl(2).

Dari hasil pemantauan alur reaksi perubahan Nitrogen dan 1-Naphtol masih belum dapat disimpulkan dengan pasti mengenai alur reaksi degradasi Carbaryl dalam kondisi anaerobik oleh bakteri denitrifikasi, karena masih ada senyawa kimia hasil perubahan 1-Naphtol yang belum diketahui. Disamping itu, reaksi denitrifikasi secara lengkap belum diketahui karena gas $\mathrm{N}_{2}$ yang terbentuk tidak dianalisa dalam penelitian ini. Terbentuknya Nitrit yang cukup tinggi pada alur reaksi dari isolat bakteri CD1 belum dapat dipastikan berasal dari hasil reaksi apa. Kemungkinan pertama adalah hasil samping dari perombakan 1-Naphtol atau merupakan senyawa intermediet dari reaksi denitrifikasi yang tidak sempurna akibat dari adanya senyawa hasil degradasi Carbaryl yang menjadi penghambat reaksi denitrifikasi. Untuk mengklarifikasi dugaan-dugaan tersebut, maka penelitian lebih detil masih harus dilakukan. Namun demikian dari penelitian ini telah diperoleh informasi awal adanya bakteri denitrifikasi yang memperlihatkan indikasi mampu mendegradasi carbaryl. Seperti diketahui bahwa laporan mengenai kemampuan bakteri denitrifikasi dalam mendegradasi pestisida (carbaryl) dalam kondisi anaerobik masih sangat terbatas.

\section{KESIMPULAN}

Dari hasil penelitian ini dapat disimpulkan bahwa beberapa isolat bakteri denitrifikasi yang diperoleh dari tanah yang tercemar pestisida memperlihatkan indikasi mampu mendegradasi senyawa Carbaryl dalam kondisi anaerobik. Reaksi denitrifikasi (perombakan Nitrat) dan degradasi Carbaryl dapat berlangsung secara simultan. Dari pemantauan alur reaksi yang terjadi dari beberapa isolat bakteri denitrifikasi yang diuji diperlihatkan adanya 2 kelompok bakteri yang mempunyai alur reaksi degradasi Carbaryl yang berbeda yaitu bakteri denitrifikasi yang hanya mampu merombak Carbaryl menjadi 1-Naphthol (isolat CL1) dan bakteri yang dapat merombak Carbaryl menjadi 1-Naphthol dan kemudian merombak 1-Naphtol menjadi senyawa tertentu lainnya yang belum terdeteksi (isolat CD1). 


\section{UCAPAN TERIMA KASIH}

Penulis mengucapkan terima kasih kepada Dr. Sarjiya Antonius atas bantuan dan sarannya dalam melakukan penelitian ini. Ucapan terima kasih juga penulis sampaikan kepada saudari Nani Mulyani, Arie Rosmalina, Yanti Dwi Lestari, saudara Entis Sutisna dan teman-teman dalam satu team proyek DIPA atas segala bantuannya sehingga penelitian ini dapat diselesaikan.

\section{DAFTAR PUSTAKA}

1. Hayatsu, M., and T. Nagata. 1993. Purification and Characterization of Carbaryl Hydrolase from Blastobacter sp. Strain M501. Appl. Environ. Microbial. 59 (7): 2121-2125

2. Swetha, Vandana P. and Prashant S. Phale. 2005. Metabolism of Carbaryl via 1,2-Dihydroxynaphthalene by Soil Isolates Pseudomonas sp. Strains C4, C5, and C6. Appl. Environ. Microbial 71 (10): 5951-5956.

3. Rajagopal BS, Rao VR, Nagendrappa G, Sethunathan N. 1984. Metabolism of carbaryl and carbofuran by soil enrichment and bacterial cultures. Can J Microbiol 30: 1458-1466.

4. Chaudry, G. R., A. Mateen, B. Kaskar, M. Bloda, and S. Riazuddin. 2002. Purification and Biochemical
Characterization of The Carbamate Hydrolase from Pseudomonas sp. 50432. Biotechnol. Appl. Biochem 36: 63-70.

5. Hallberg R. 1987. Agricultural chemicals in groundwater: extent and implications. Am J Alter Agric. 2(1): 3-15

6. Aslan S, Turkman A. 2005. Combined biological removal of nitrate and pesticides using wheat straw as substrates. Process Biochemistry. 40:935-943.

7. Larkin MJ, Day MJ. 1986. The metabolisms of carbaryl by three bacterial isolates, Pseudomonas spp. (NCIB 12042 \& 12043) and Rhodococcus sp. (NCIB 12038) from garden soil. J Appl Bacteriol. 60:233242.

8. Bollag J.M, Liu SY (1971). Degradation of sevin by soil microorganism. Soil Biol Biochem 3:337-345

9. Rodriquez LD, Dorough HW. 1977. Degradation of carbaryl by soil microorganism. Arch Environ Contam Toxicol 6:47-56.

10. Vontor, T., J. Socha, and M. Vecera. 1972. Kinetics and Mechanism of Hydrolysis of 1-Naphthol, N-methylcarbamate and NN-dimethylcarbamates. Collect. Czeeh. Chem. Commun. 37 : 21832196 